\title{
A Prototype Calix[4]arene-based Receptor for Carbohydrate Recognition Containing Peptide and Phosphate Binding Groups
}

Margarita Segura, Barbara Bricoli, Alessandro Casnati, Eva Maria Muñoz, Francesco Sansone, Rocco Ungaro, Cristina Vicent

\section{Supporting information}

\section{Table of Contents}

\section{Experimental General Methods}

Figure S1. ${ }^{1} \mathrm{H}$ NMR spectrum of pseudopeptide $4 \mathbf{a}$

Figure S2. ${ }^{1} \mathrm{H}$ NMR spectrum of pseudopeptide $\mathbf{4 b}$

Figure S3. ${ }^{1} \mathrm{H}$ NMR spectrum of calixarene 8

Figure S4. ${ }^{1} \mathrm{H}$ NMR spectrum of receptor 10a

Figure S5. ${ }^{1} \mathrm{H}$ NMR spectrum of receptor $\mathbf{1 0 b}$

Figure S6. ${ }^{1} \mathrm{H}$ NMR spectrum of receptor 11a

Figure S7. ${ }^{1} \mathrm{H}$ NMR spectrum of receptor $\mathbf{1 1 b}$

Figure S8. COSY NMR spectrum of receptor 10a

Figure S9. COSY NMR spectrum of receptor 11a

Figure S10. COSY NMR spectrum of receptor $\mathbf{1 2}$

Figure S11. ${ }^{1} \mathrm{H}$ NMR spectra of free receptor 12 and of the mixture 12:octyl- $\beta$-glucopyranoside 1:5.

Figure S12. NOESY NMR spectrum of receptor 12

Figure S13. NOESY NMR spectrum of the 1:1 12: $\beta$-octylglucoside complex 


\section{Experimental section}

General Methods: All moisture sensitive reactions were carried out under nitrogen atmosphere. Dry solvents were prepared according to standard procedures and stored over molecular sieves. Melting points are uncorrected and were determined in under nitrogen sealed capillaries with an Electrothermal apparatus. ${ }^{1} \mathrm{H}$ and ${ }^{13} \mathrm{C}$ NMR spectra were recorded at 300 and $400 \mathrm{MHz}$ and 75 $\mathrm{MHz}$, respectively, at $300 \mathrm{~K}$ unless otherwise specified (partially deuterated solvents were used as internal standard). The reported $J$ values are referred to $\mathrm{H}, \mathrm{H}$ coupling constants, unless other specifications. Mass spectra were registered in ESI and $\mathrm{CI}\left(\mathrm{CH}_{4}\right)$ mode. Elemental analyses are reported as percentage. TLC, sheets and flash chromatography were performed on silica gel Carbohydrates 14a-c were synthesised as described in literature. ${ }^{[19]} \mathrm{CDCl}_{3}$ used for ${ }^{1} \mathrm{H}$ NMR titration experiments was freshly dried over neutral aluminium oxide.

For reasons of clarity and in order to reduce space, the name calix[4]arene was used instead of the original IUPAC name: pentacyclo[19.3.1.1 $\left.1^{3,7} \cdot 1^{9,13} \cdot 1^{15,19}\right]$ octacosa1(25),3,5,7(28),9,11,13(27),15,17,19(26),21,23-dodecane.

NMR titration experiments: ${ }^{1} \mathrm{H}$ NMR titration experiments with monosaccharides 13a-e were performed by addition of a $8.8 \times 10^{-3} \mathrm{M}$ solution of the guest to a $1.0 \times 10^{-3} \mathrm{M}$ solution of the host, going from a $2: 1$ to a $1: 9$ host/guest ratio. On the contrary, with carbohydrates $14 a-c$, a $1.0 \times 10^{-4} \mathrm{M}$ solution of the guest was titrated with a solution mixture of host $\left(1.0 \times 10^{-3} \mathrm{M}\right)$ and guest $\left(1.0 \times 10^{-4} \mathrm{M}\right)$ in order to keep constant the concentration of these carbohydrates which experience self-association at concentrations above $10^{-4}$ M. 


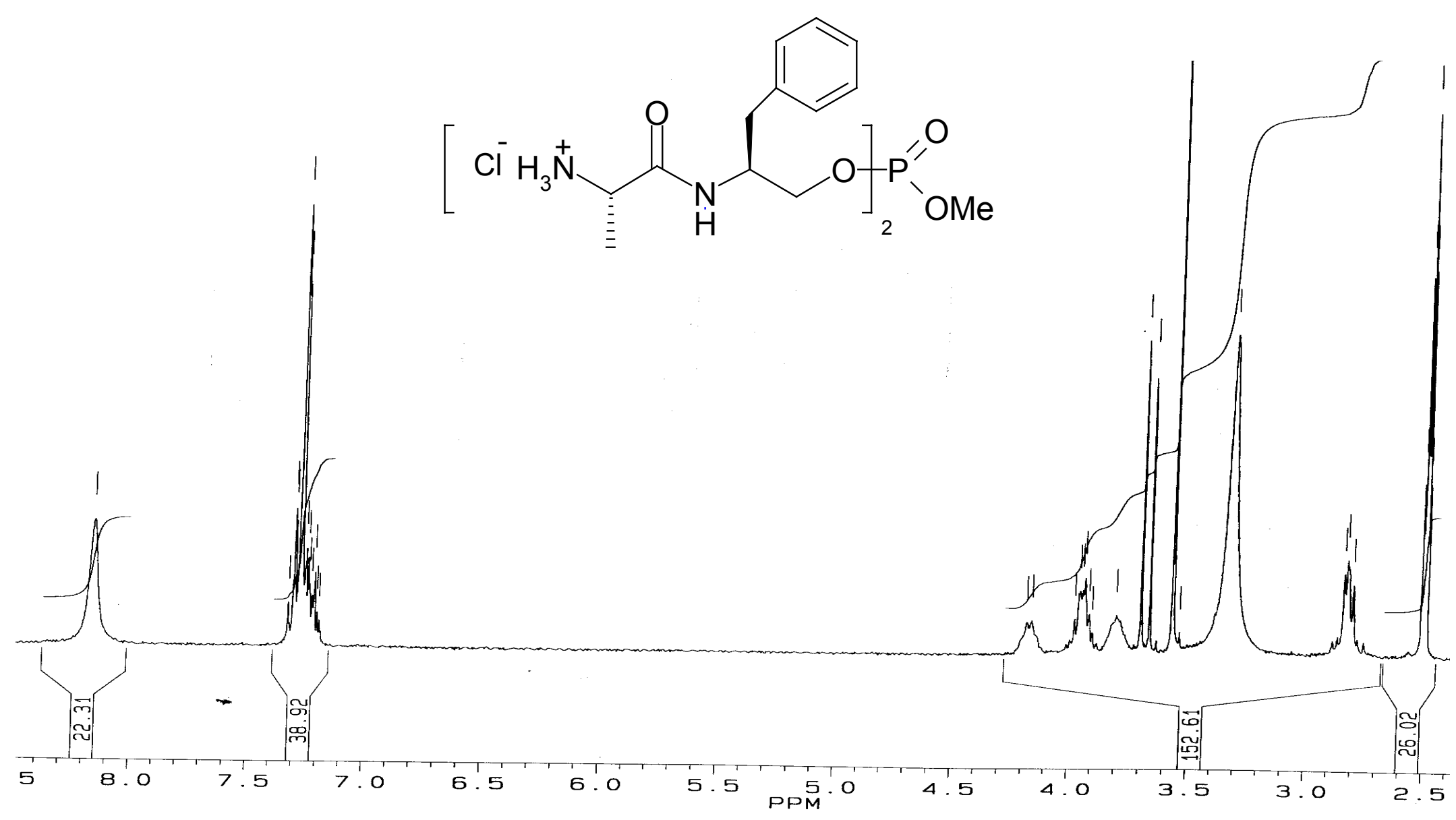

Figure S1. ${ }^{1} \mathrm{H}$ NMR of compound $\mathbf{4 a}$ in $\mathrm{CDCl}_{3}(300 \mathrm{MHZ}, 300 \mathrm{~K})$ 


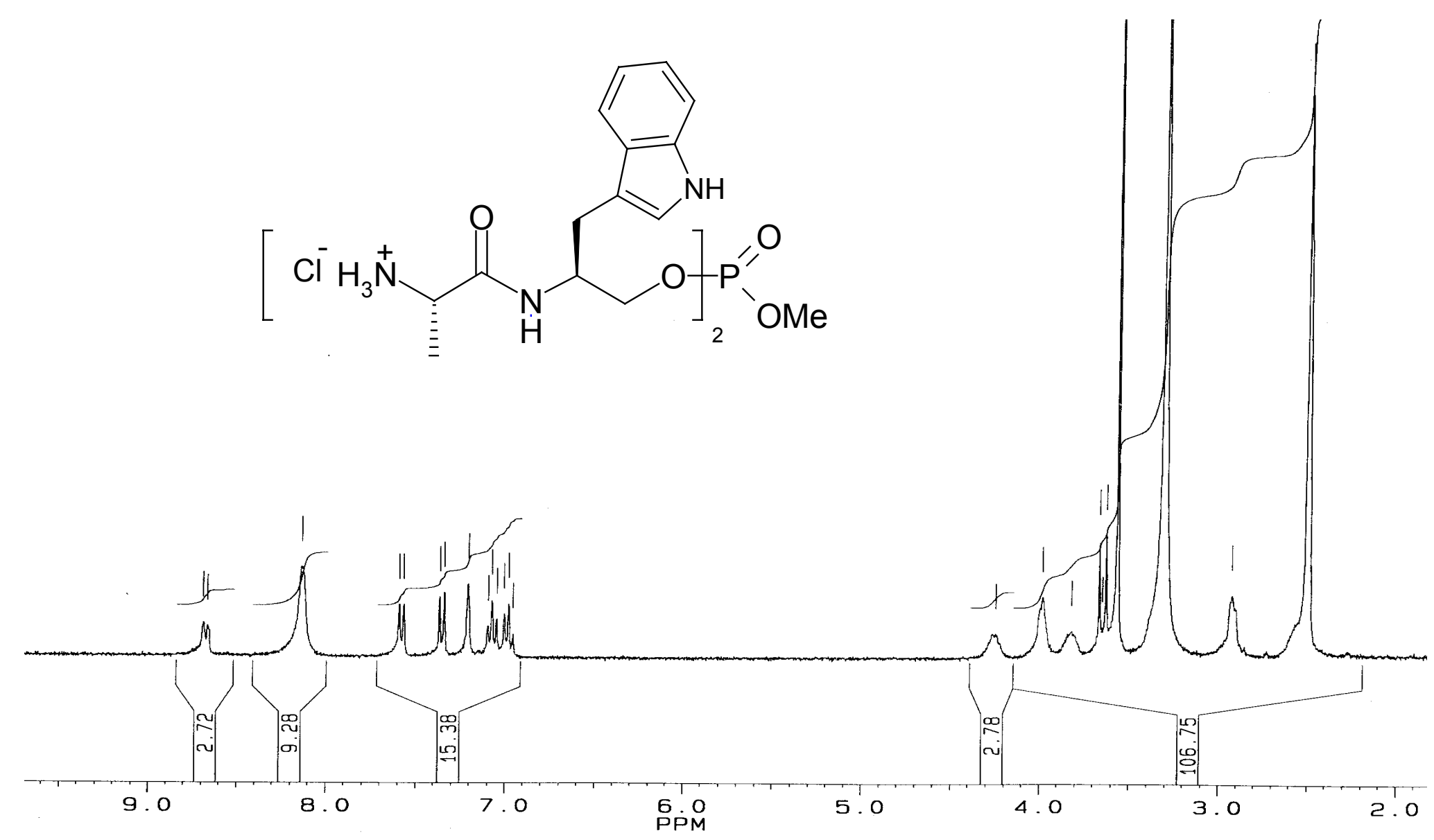

Figure S2. ${ }^{1} \mathrm{H}$ NMR of compound $\mathbf{4 b}$ in $\mathrm{CDCl}_{3}(300 \mathrm{MHZ}, 300 \mathrm{~K})$ 


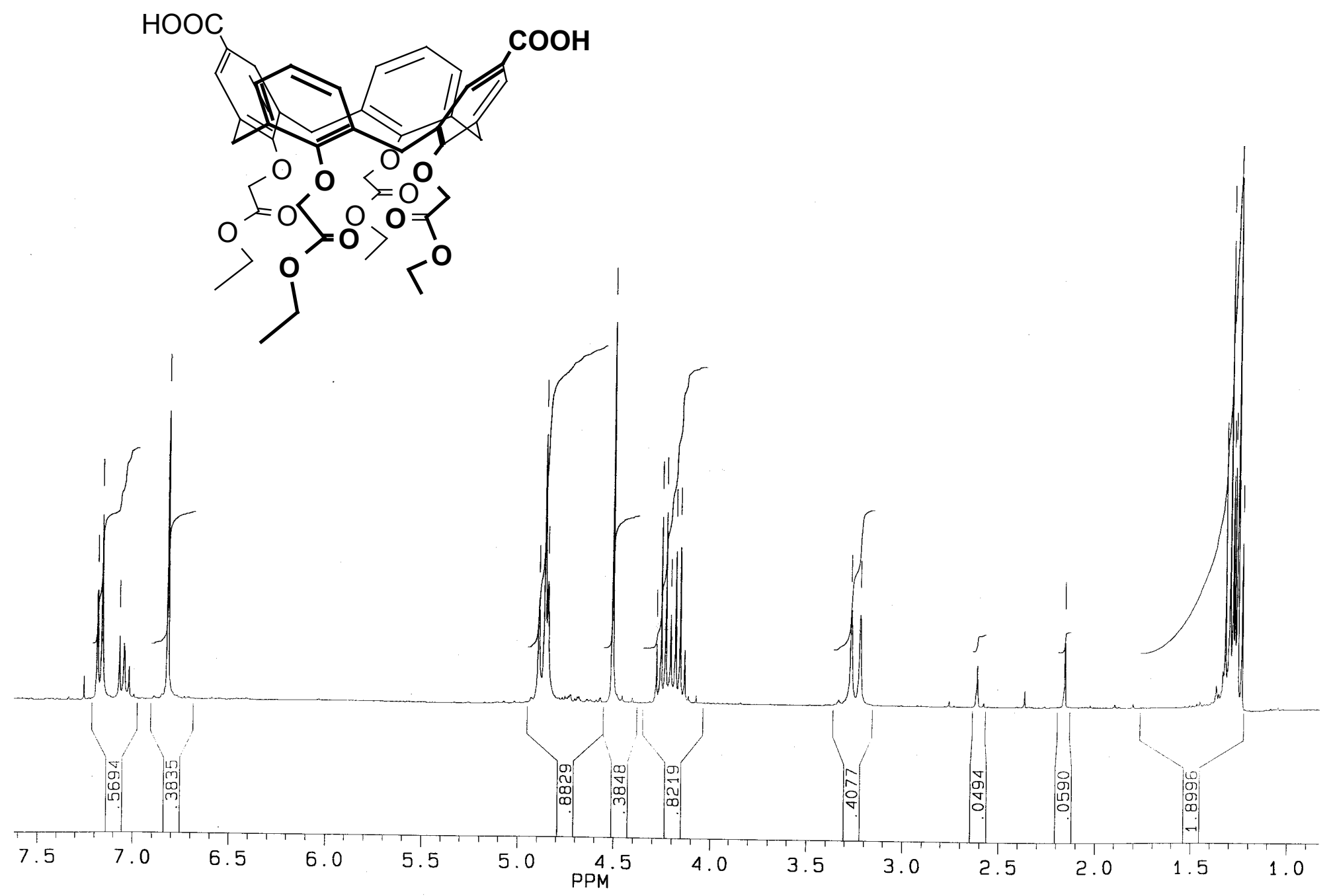

Figure S3. ${ }^{1} \mathrm{H}$ NMR of compound 8 in $\mathrm{CDCl}_{3}(300 \mathrm{MHZ}, 300 \mathrm{~K})$ 


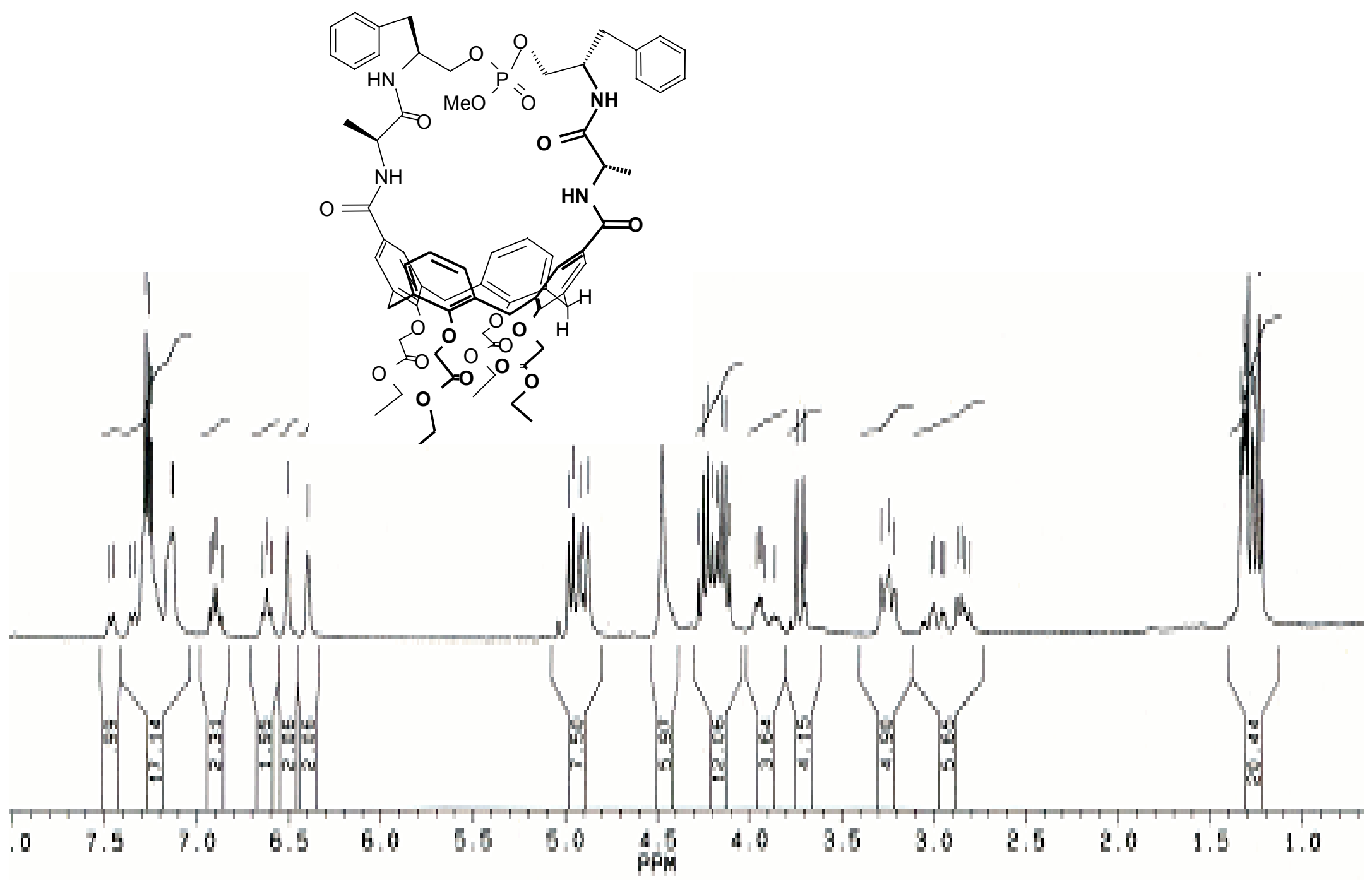

Figure S4. ${ }^{1} \mathrm{H}$ NMR in $\mathrm{CDCl}_{3}(300 \mathrm{MHz}, 300 \mathrm{~K})$ of compoud 10a 


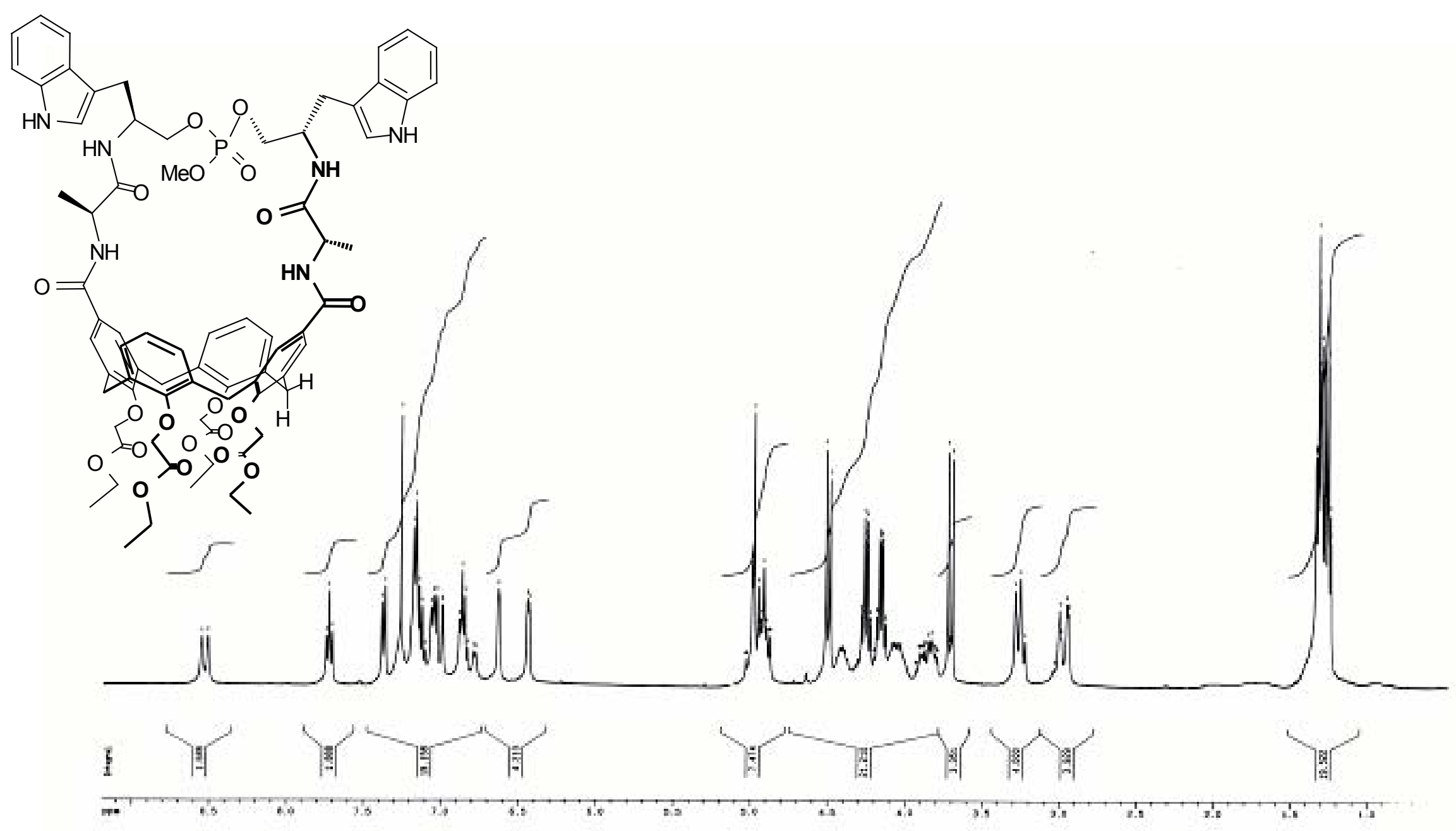

Figure S5. ${ }^{1} \mathrm{H}$ NMR in $\mathrm{CDCl}_{3}(300 \mathrm{MHz}, 300 \mathrm{~K})$ of compound $\mathbf{1 0 b}$ 


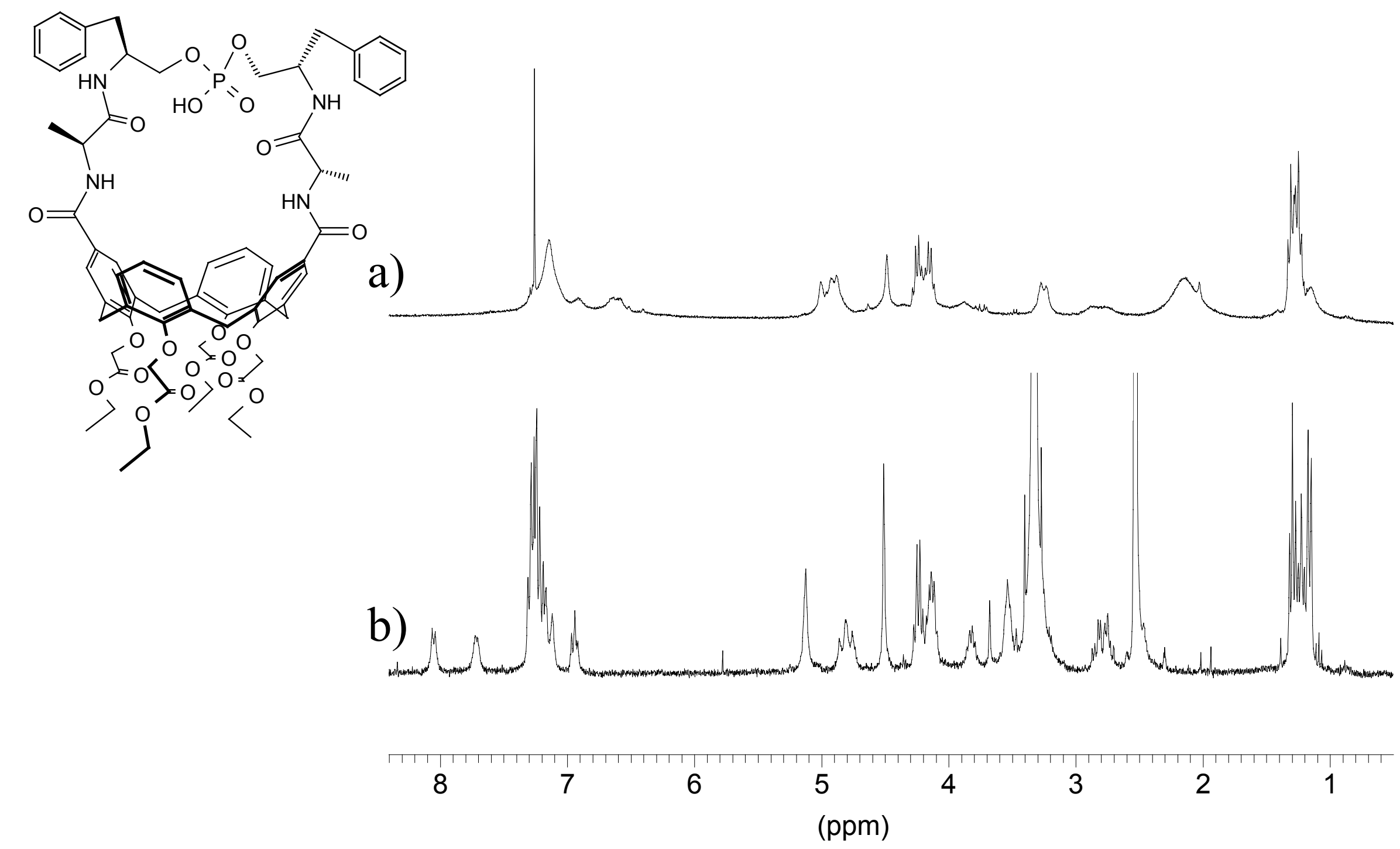

Figure S6. ${ }^{1} \mathrm{H}$ NMR $(300 \mathrm{MHz}, 300 \mathrm{~K})$ in a) $\mathrm{CDCl}_{3}$ and b) DMSO- $d_{6}$ of compound 11a 


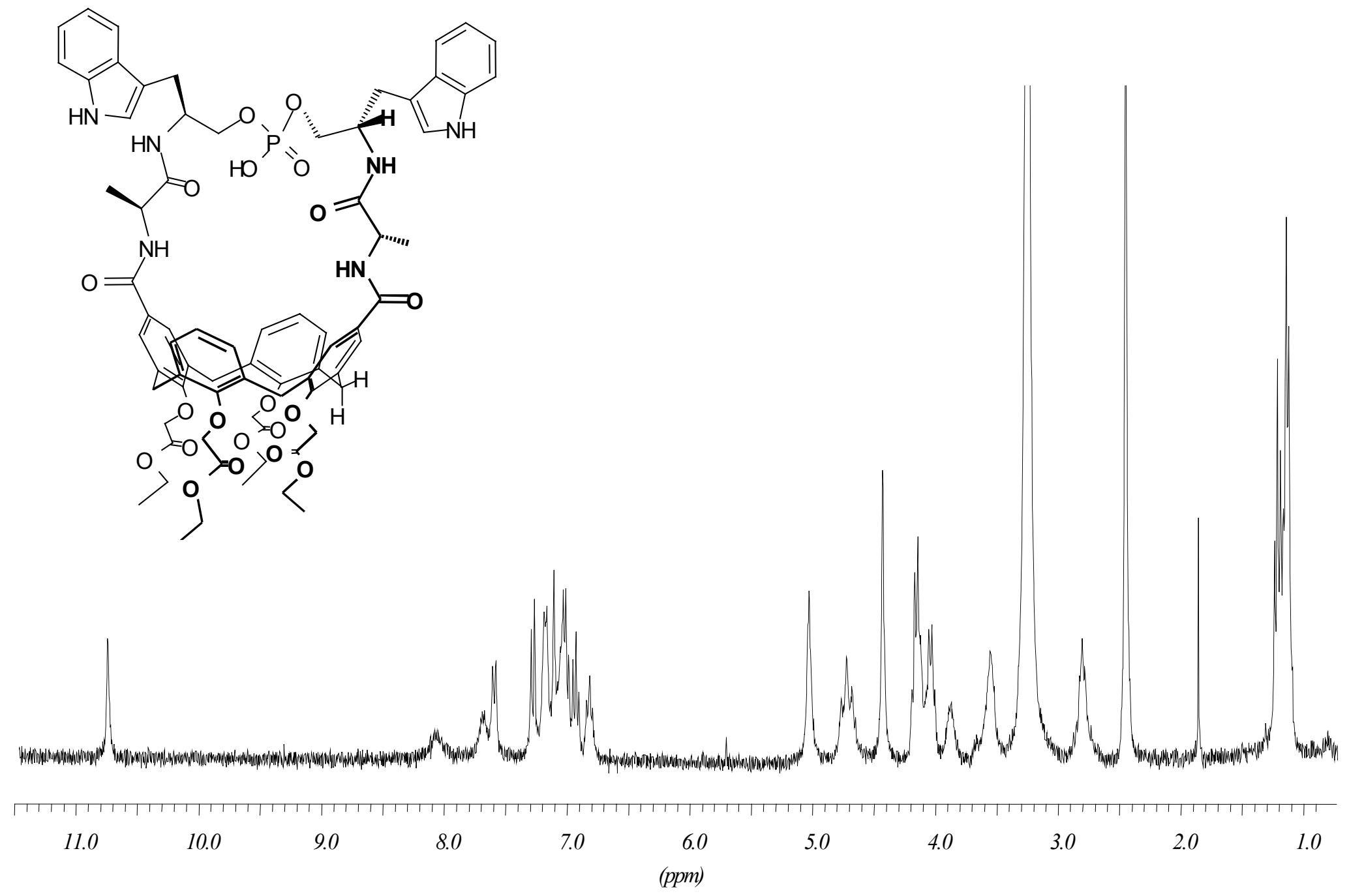

Figure S7. ${ }^{1} \mathrm{H}$ NMR in DMSO- $d_{6}(300 \mathrm{MHz}, 300 \mathrm{~K})$ of compound $\mathbf{1 1 b}$ 
Figure S8.

COSY NMR in $\mathrm{CDCl}_{3}$ of compound 10a (300 MHz, 300K).
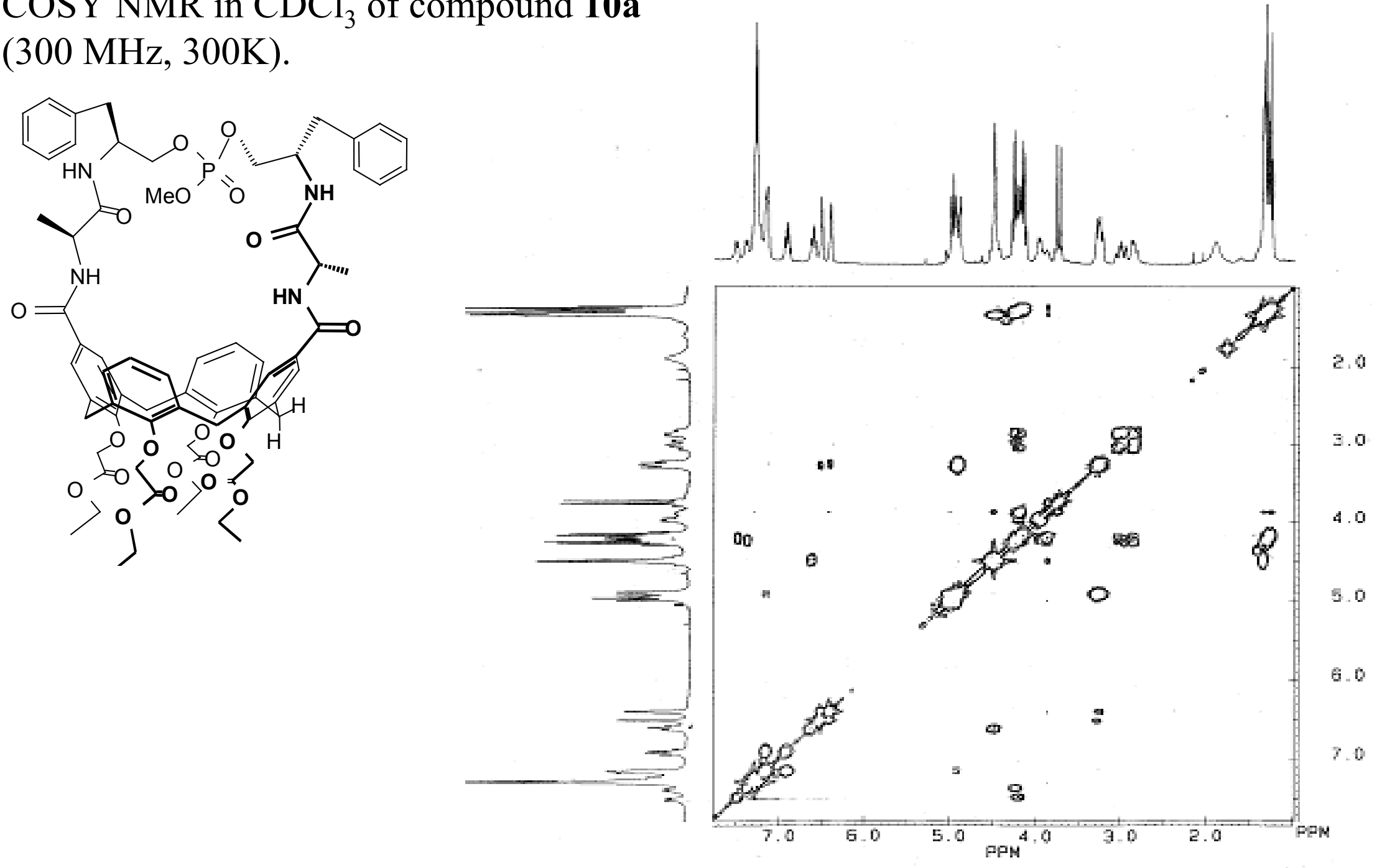
Figure S9.

COSY NMR in DMSO- $d_{6}$ of compound 11a (300 MHz, 300K).
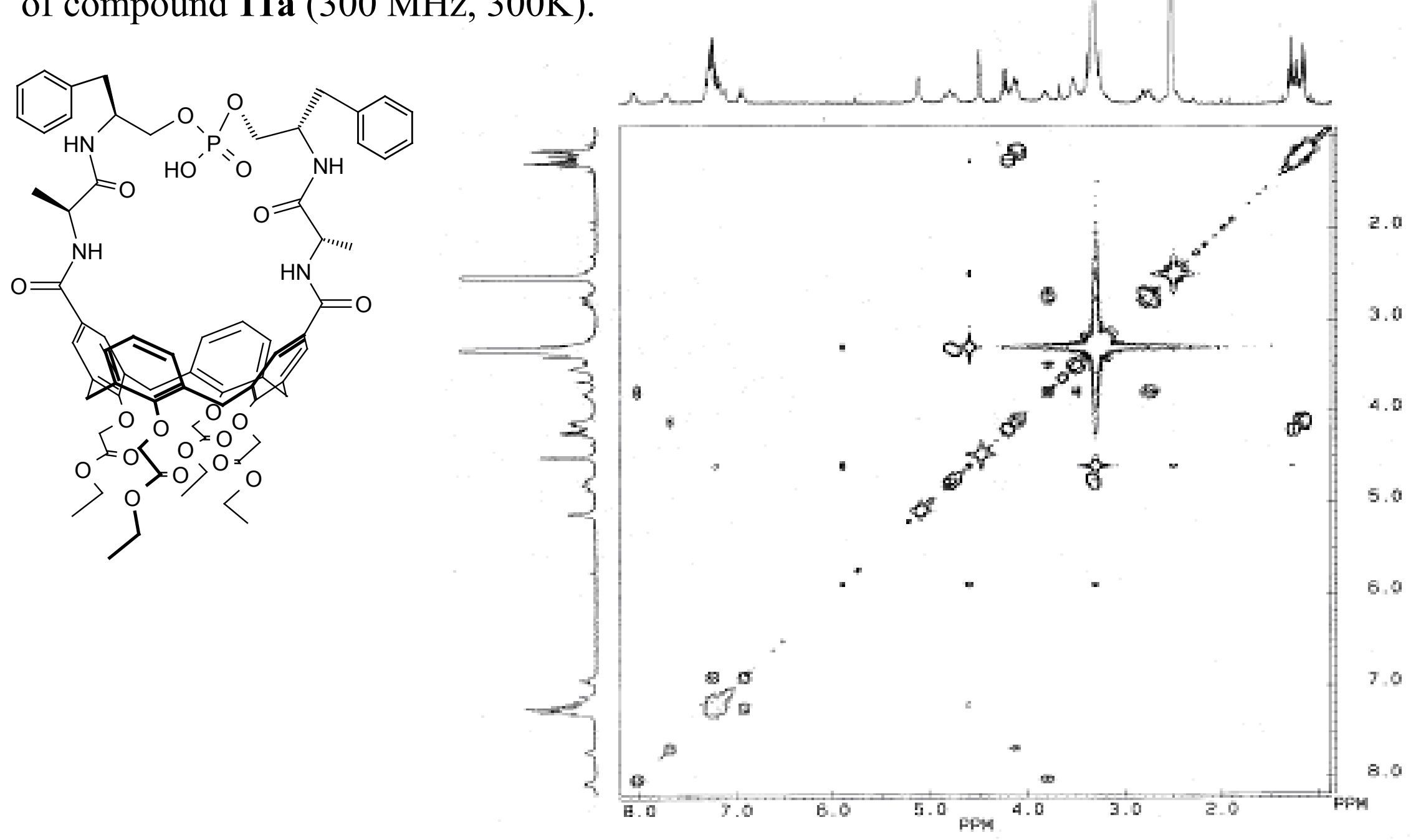
Figure S10.

COSY NMR in $\mathrm{CDCl}_{3}$ of receptor 12 (300 MHz, 300K)
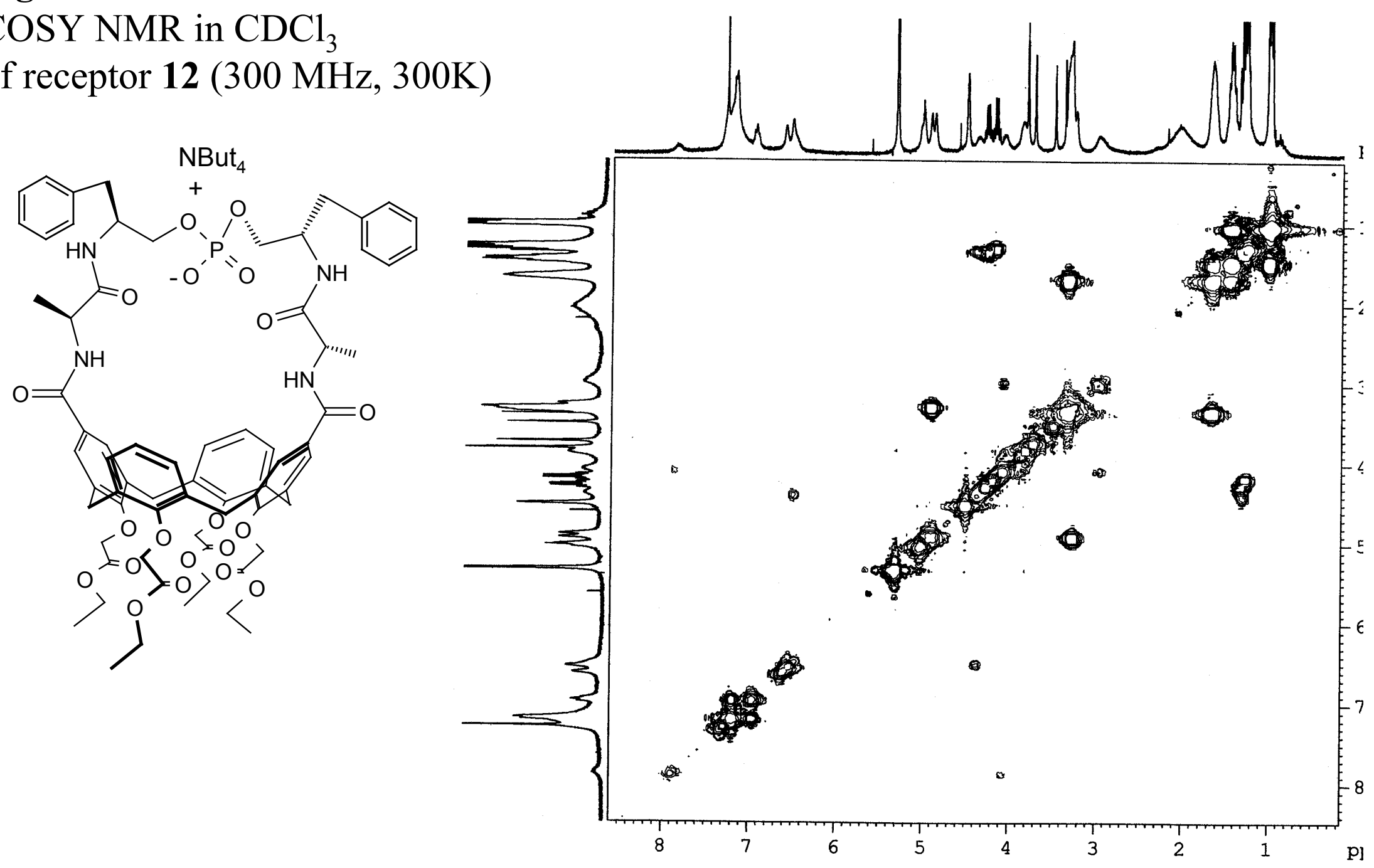


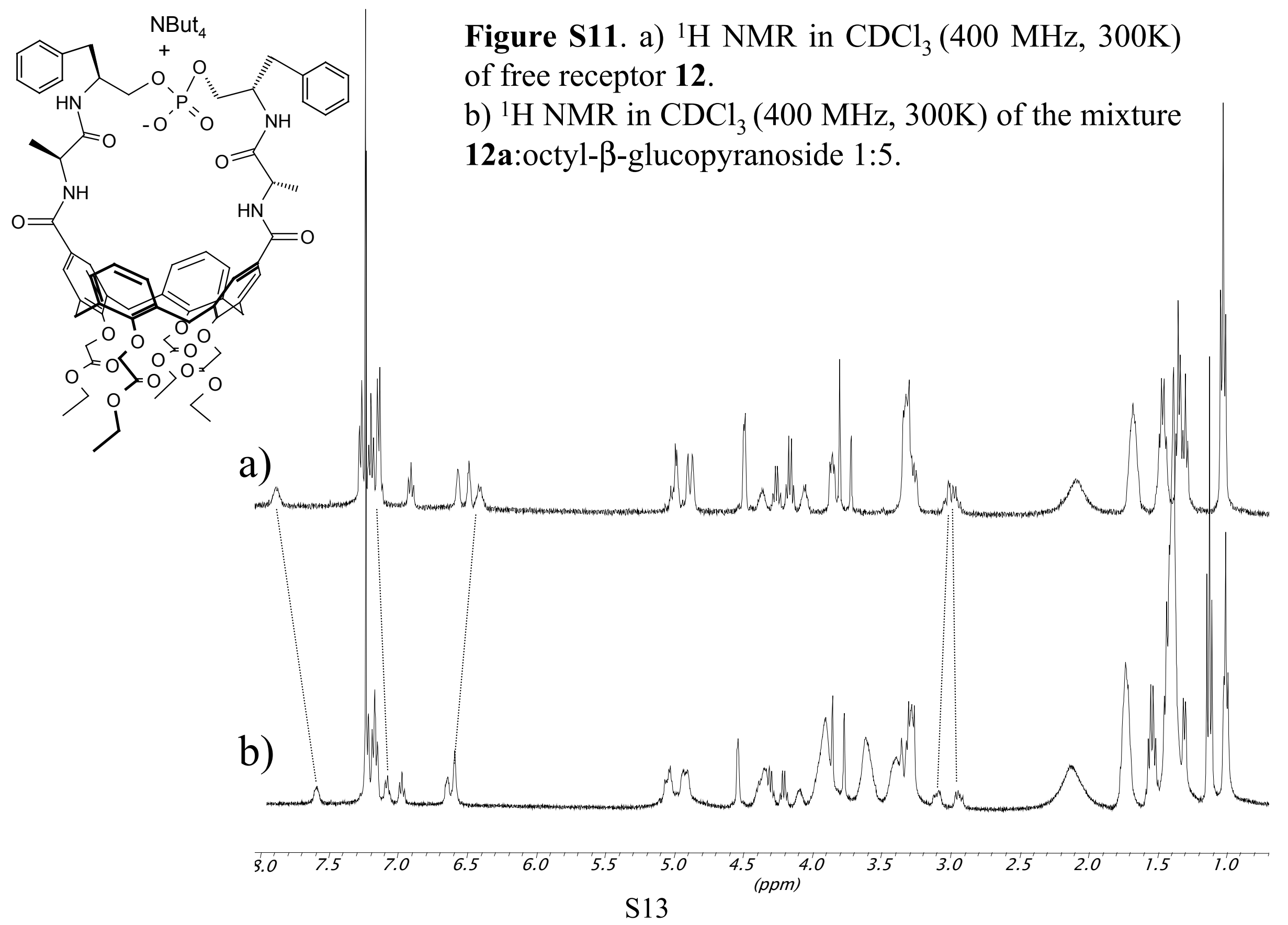


Figure S12. NOESY NMR in $\mathrm{CDCl}_{3}$ of receptor 12 (300 MHz, 300K)

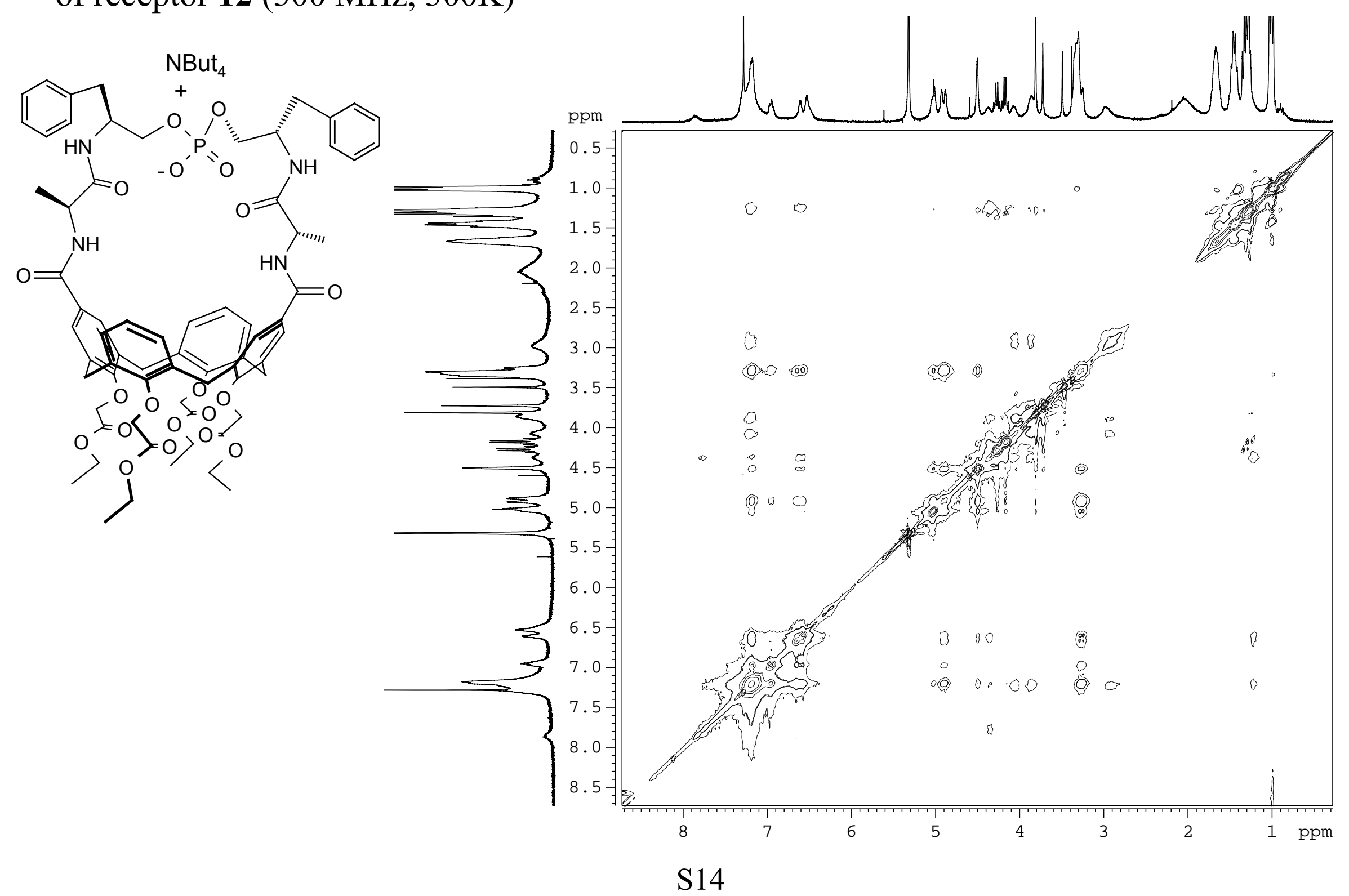


Figure S13. NOESY of the

1:1 complex between receptor 12 and $\beta$-octylglucoside 13a
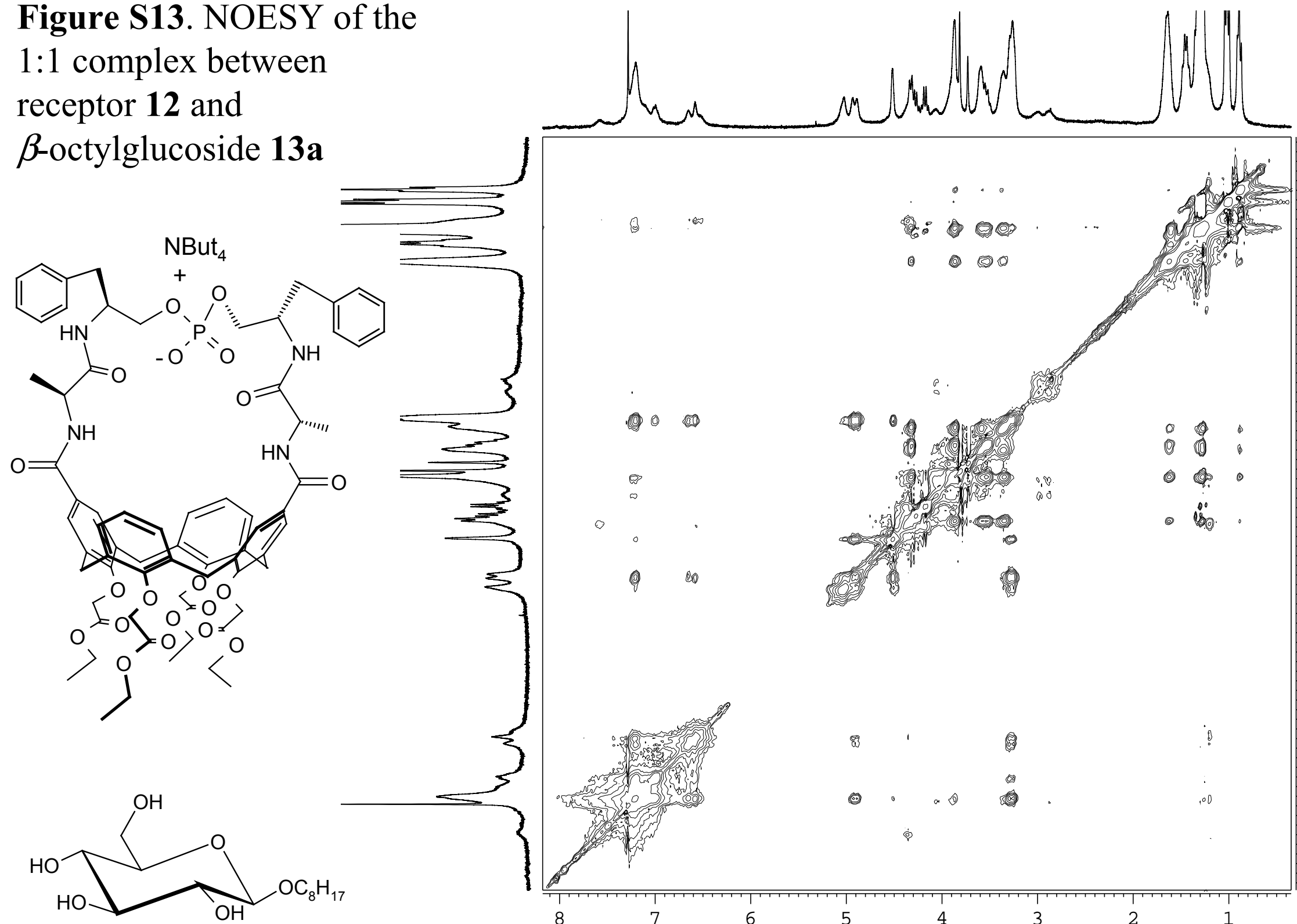